\title{
Students' Attitudes on Social Network Sites and their Actual Use for Career Management Competences and Professional Identity Development
}

\author{
https://doi.org/10.3991/ijet.v12i05.6778 \\ Andreja Istenic Starcic \\ University of Ljubljana, Slovenia \\ University of Primorska, Koper, Slovenia \\ andreja.starcic@gmail.com \\ Margaret Barrow \\ City University New York, BMCC, New York, USA \\ mbarrow@ bmcc. cuny . edu \\ Matej Zajc \\ University of Ljubljana, Ljubljana, Slovenia \\ matej.zajc@fe.uni-lj.si \\ Maja Lebenicnik \\ University of Primorska, Koper, Slovenia \\ maja.lebenicnik@pef.upr.si
}

\begin{abstract}
Social network sites (SNSs) have become strategic networking tools for employment-related activities. They shape professional identity and influence professional and career practices, providing new paths for career, employment and recruitment processes. Students' professional identity is influenced by their career management and work experience. There is a lack of research on the use of SNSs for students' on-line career management competences. A survey was conducted to examine students' attitudes regarding the use of SNSs for career management competences and professional identity development. The student's attitudes revealed career control, networking for learning, career reflection, self-presentation and work exploration as predictors for students' actual use of SNSs for career management and professional identity development. For the career competences the main influencing predictors were found to be students' beliefs that SNSs support work exploration, processes of self-presentation and career control. For professional identity development, the main influencing predictors were students' beliefs that SNSs support career control and students' engagement in professional events through networking for learning. Findings could contribute to understanding and facilitation of the SNS-related career management competences.
\end{abstract}

Keywords- Social network sites, Higher education, Career, Competences, Professional identity, Social media, Networking, Computer assisted learning 


\section{Introduction}

Students are in the phase of emerging adulthood, during which the exploration of professional, career and work issues is significant. Students' identity development is intertwined with their explorations and decisions concerning their emerging professionalism. At this stage, their professional identity development is very intensive. Today, students face a dynamic, complex, competitive and unpredictable work market, and employers expect graduates to already have related work experience. To be successful in their job searches during their college years and their first years of employment, students must have certain career management competences. University is typically the first stage of life-long professional development, during which one engages in formal and informal education and work activities and grows from novice to expert. In the past, professional development was conducted within specific professions and was primarily concerned with competency and vertical progression. In contemporary society, however, professional development faces a dynamic and unpredictable work market, and new market entrants must be self-reliant in managing their careers to ensure life-long employability and to transition among jobs. Career competences, such as knowledge, skills and career development abilities, can be influenced by individuals [1], focus on planning and development, are related to life-long career development and are intertwined with professional development [2].

Previous research findings indicate that students' professional identity development is influenced by work experiences and career decision self-efficacy [3] or career management competences [4]. Jackson and Wilton [2,1] highlight the influence of career management competences in identity development, showing that these competences affect self-efficacy and goal achievement, employability and long-term career success.

In today's job market, social network sites (hereafter SNSs) are shaping professional identity [5, 6]. Identity-related processes in social network sites include reflective identity making, narrative identity making and active identity making [6]. These three processes are applied in this article to the discussion of professional identity development and career management competences. Interpretation of and reflection on an individual's career and career management is based on subjective perceptions of the career-developing narrative, which connects past, present and future and is linked to a person's identity [4].

SNSs "have become more media-centric and less profile centric" [7]. The dynamic nature of self-presentation requires profile and permanent status updates comprising descriptive texts presenting experiences [7]. Norms of self-presentation and styles of communication are specific to professional fields [8], and they are reshaping professional practices, providing new paths of professional and career engagement and reshaping employment and recruitment practices. In the area of SNSs, studies have been conducted on the social capital, job search and business connections of university students [9], on building social capital to foster students' employability [10], on social media skills for career management [11], and on impacts of education intervention in the application of social media in the career domain $[12,5]$. However, there is a lack of research on SNSs for the development of online career management competences 
[13], social media skills for career success [11] and employability skills and career prospects for graduates [10]. In this paper, we examine students' perceptions of SNS use for career management competences and professional identity development.

The research findings indicate that students utilise SNSs for personal purposes [14, 15] and not sufficiently for professional engagement. Furthermore, students' levels of awareness and beliefs concerning how their SNS visibility affects their future career opportunities vary $[16,17]$.

\section{SNSs in higher education shape students' professional identity}

Professional identity is a critical constituent of identity [18, 19], such that people tend to define themselves by their professions in social settings. Giddens [20], Christiansen and Bryan [18] and Phelan and Kinsella [19] all support the notion that professional identity points to "future and possible selves [18]." University education and the stage of emerging adulthood is a state of institutionalised moratorium characterised by intensive exploration and delayed decisions [21]. During this time, students are searching for their career and professional identities in the context of their personal identities as they cross the border between different systems of academic and professional environments, lifestyles and recreational activities (some of which occur more frequently on SNSs). Developing a professional identity, according to Christiansen and Bryan [18], involves daily and long-term activities of: (1) shaping and being shaped by relationships with others, (2) participating in activities and interpreting actions in relationship to others and (3) developing a self-narrative or life story when making sense of daily experiences and life.

Identity construction is related to social integration and supported by narrationthe stories we create about ourselves. In research concerning the self and identity, Giddens [20] suggested that self-identity is constructed and sustained by narratives about the self, emphasizing that individuals construct identity through narration as a trajectory from the past to anticipate the future. Overall, identity is premised on people's behaviours in interactions with others.

SNSs are recognized as important spaces for the construction of professional identity [12]. As such, SNSs have become spaces for activities related to identity development, and they influence how people understand themselves [6]. Orsatti and Riemer [6] developed a framework for researching identity, noting that people can engage in SNSs through reflective, narrative and active modes. Reflective identity making constitutes how we think about ourselves based on past experiences, goalsetting and the performance of intentional identity-building strategies. Selfpresentation as a constitutive element of identity is formed within a reflective and narrative identity making process and includes deliberate strategies of selfpresentation [6]. Giddens [20, 22] viewed self-identity as reflexive practice of an individual's biography and contended that social identity is connected to obligations, sanctions and rights, which are associated with roles within a collective or group. According to Christiansen and Bryan [18], a reflective process in identity formation 
involves thinking about and reflecting on oneself from the perspective of other possible selves and images of action. In SNSs, a person's profile reveals identity through presentation, which is multimodal and includes text, photos, images, video and communication history. Walther et al. [22] argued that the impression and attractiveness of a profile owner are affected by communication in terms of messages with other members, pictures and other posts, all of which are used to interpret a member's character. Narrative identity making constitutes a shared narration and social experience in diverse contexts. Designing a coherent life story constitutes selective turning points in life and various shared stories of a person's diverse social contexts. Active identity making constitutes everyday action and interaction within social practices (e.g. professional practice) and how people connect with and/or relate to the identity being shaped in a variety of processes. For example, consider on-line communities of practice, where the focus is on "learning to be" through "enculturation into practice" [23] and learning situated in social and cultural environments participating in the core practices of the community [24].

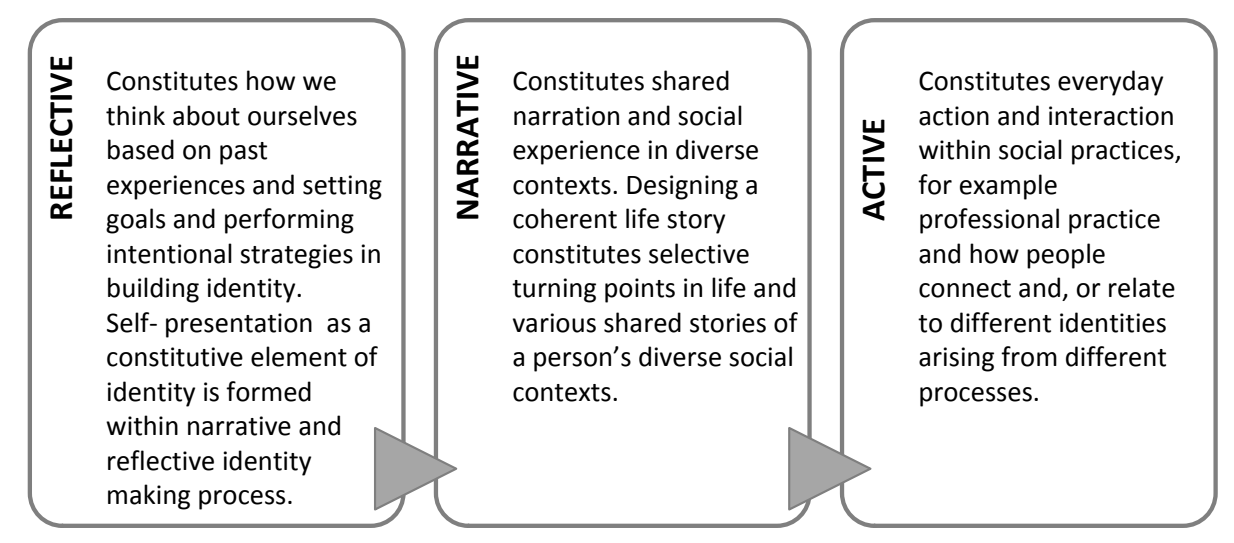

Fig. 1. Reflective, narrative and active identity making by Orsati and Riemer, [6]

\section{SNSs for career management}

In professional life, SNSs support professional networking [25], reshape recruitment practices and job searches [26], and are widely recognised as career enhancement tools [12]. A high percentage of jobs are obtained through social networks [25], which have proven to be 30 percent faster than other traditional recruitment practices and are increasing opportunities for international recruitment [27]. Networking has become a key strategy in building social capital and maintaining employment [8], and graduates who have strong social capital have been shown to be better at job searches and career orientations [11]. Individuals who network in relation to their career aspirations get more social support [1]. Job search practices transition to networking in SNSs, and positive correlations have been identified between networking duration and 
number of job offers [28]. Internet practices also provide candidates with more information about companies and job descriptions [29].

On the other hand, job applicants with on-line profiles and images face more critical examination, since recruiters often screen job applicants' online activities. According to Careerbuilder, 60 per cent of employers use SNSs to screen job candidates [40]. Job seekers' predictors for career-oriented self-disclosure versus inappropriate self-disclosure include beliefs that SNSs could support their professional image, social media self-efficacy, and the effectiveness of social media as a channel for searching for employment [16]. Students who are already engaged in studying, preparing for their careers and conducting social networking with potential employers are more successful in finding their first jobs [30, 31]. Higher education should address employability skills through career management [32] and SNS-related opportunities for career management [10]. It is necessary for job seekers to explore career management competences through career social networking skills. However, offline career management competences cannot be transferred online [13].

Career management is the ability to build one's own career. To secure employability in the complex world of work, graduates must be skilled in career management [32]. A variety of career competence models exist. Many of these focus on selfanalysis, matching individuals with labour market opportunities and workplace effectiveness[4]. For the purposes of the present study, Kuijpers and Scheerens' [33] fourlevel model of career management competences was applied. This model provides a framework for the self-reflection and self-evaluation of abilities, motives and career preferences, as well as for the identification of career opportunities and the making of appropriate career decisions. According to Kuijpers and Scheerens [33], career management competences, as presented in Figure 2, comprise: self-presentation (SP), career-reflection (CR), work exploration (WE) and career control (CC). SP includes presentation in work and networking, $\mathrm{CR}$ includes reflection on capacities and reflection on motives, WE includes orientation to work and orientation to mobility and $\mathrm{CC}$ involves career planning, control of learning processes, control of work processes and balancing work and private life [33].

Kuijpers and Scheerens' [33] model fits well with Orsatti and Riemer's [6] concept of professional identity development in SNSs. Narrative identity making is consistent with SP, reflective identity making with self-reflection and SP, and active identity making with $\mathrm{CC}$ and WE.

Career management has become an important part of professional life, as modern individuals' career patterns change more often today than they did in the past. In this process, SNSs influence employment-related activities [8] and offer possibilities to connect in formal and informal social networks, screen for potential employers, search for jobs, etc. [31]. Facebook, adopted by young generations for personal purposes, has also become extensively used for professional and job networking purposes [12]. On the other hand, LinkedIn, which was designed as a professional SNS, is the largest professional matchmaker site in the world [34]. The belief that people's careers can be shaped through branding in social network sites is subject to discussion $[5,35]$. The Pew Internet and American Life Project [36] reports that $90 \%$ of young adults in the US who use the Internet also use SNSs. The age group of 18- to 29-year- 
olds represents $82 \%$ of Facebook users and $22 \%$ of LinkedIn users. However, while students use SNSs extensively, they may not be aware of the potential of SNSs as career enhancement tools [12].

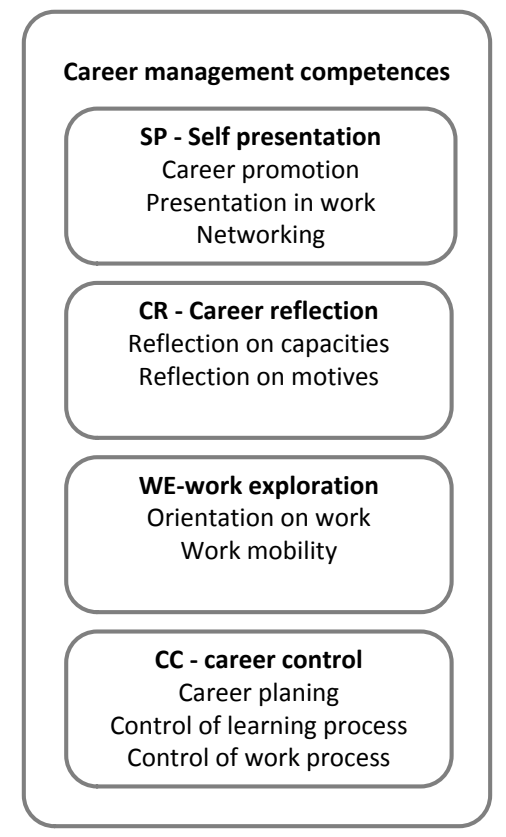

Fig. 2. Career management competences by Kuijpers and Scheerens, [33]

Therefore, SNSs and their influence and usefulness as professional tools and resources for student resources need to be examined, particularly with respect to the ways in which students perceive and utilize SNSs and how they shape and reshape professional identities as students cross the boundary between academic and workplace environments.

The research questions:

(1) Which are dimensions of students' attitudes towards the use of SNSs for career management competences and professional identity development?

(2) How do attitudes influence students' actual use of SNSs for career management competences and professional identity development?

Hypothesis:

Hypothesis 1: Students' attitudes towards using SNSs to support career management competences and professional identity development comprise several dimensions reflecting theoretical models of career management competences [33] (selfpresentation, career reflection, work exploration, career control) and Identity-making [6] (narrative, reflective and active).

Hypothesis 2: Students' attitudes towards SNSs as support tools for selfpresentation, career reflection, work exploration and career control positively affect their actual SNS use for career management competences. 
Hypothesis 3: Students' attitudes towards SNSs as support for self-presentation, career reflection, work exploration and career control have positive effects on their actual SNS use for professional identity development.

\section{$4 \quad$ Methods}

\subsection{The survey and participants}

The survey was conducted at the University of Ljubljana Faculty of Civil and Geodetic Engineering, which provides the only geodetic engineering study program in the state and is one of two Faculties in civil engineering. The sample comprises 224 students enrolled in the 2015/16 academic year of a total of 390 students from this faculty and $33 \%$ of the total number of students at the national level.

Table 1. Demographic structure and Facebook and LinkedIn use

\begin{tabular}{|c|c|c|c|}
\hline & Category & $\mathbf{N}$ & $\%$ \\
\hline \multirow{2}{*}{ Gender } & Male & 134 & 60 \\
\hline & Female & 90 & 40 \\
\hline \multirow{2}{*}{ Age } & 21-22 years & 114 & 51 \\
\hline & 23-25 years & 110 & 49 \\
\hline \multirow{3}{*}{ Years of Facebook use } & 7-8 years & 103 & 46 \\
\hline & 5-6 years & 70 & 31 \\
\hline & 4- years & 51 & 23 \\
\hline \multirow{2}{*}{ Years of LinkedIn use } & $1-2$ years & 54 & 24 \\
\hline & 0 years & 170 & 76 \\
\hline
\end{tabular}

\subsection{Instrument design, validity and reliability}

The original questionnaire was designed to collect: 1) demographic data, 2) actual usage of Facebook and LinkedIn for career management competences and professional identity development (2 items) and 3) attitudes towards Facebook and LinkedIn in relation to career management competences and professional identity development (41 items). A five-point Likert scale was applied (5- strongly agree, 4 - agree, 3 undecided, 2 - disagree, 1- strongly disagree) to measure data listed under points 2) and 3). The underpinning theoretical models for items construction were Career management competences [33] and Identity-making [6].

A principal component analysis, applying Varimax rotation method, was performed to identify and measure the characteristics of the multi-item instrument, measuring attitudes. Results showed that the first factor accounted for $21.62 \%$ of the variance, indicating construct validity. The factor loadings were significant (over .5) [36]. The reliability of the questionnaire was confirmed with Cronbach's alpha coefficient, which indicated high reliability $\alpha>0.8$. Regarding content validity, the questionnaire was discussed and re-checked for clarity with experts and students. 


\subsection{Data analysis}

Data analysis was conducted with statistical program SPSS (Version 23). A principal component analysis applying the Varimax rotation method was conducted to explore the factorial structure of the attitude scale. For each factor Cronbach's alpha was calculated to check the reliability. The multiple regression analyses were conducted using the Stepwise method to assess the impact of the predictor variables (five independent variables: factors $\mathrm{CC}, \mathrm{NL}, \mathrm{CR}, \mathrm{SP}$, and $\mathrm{WE}$ ) on the two dependent variables (actual use of SNSs for career management competences and professional identity development).

\section{$5 \quad$ Results}

\subsection{Attitudes and beliefs towards SNSs support career management competences and professional identity development}

The results of the principal component analysis applying the rotation method identified five dimensions, representing attitudes on professional identity development and career management competences:

- CC - career control [33] (comprising items relating to SNSs' impacts on professional identification, provide support in professional networking otherwise impossible, a sense of belonging to a professional community, career decisions and career plans, plans for people with whom one would network in the future, agreement that visibility in SNSs support a successful job search during college years and after graduation and engagement in SNSs supports skills for professional presentation) is consistent with active identity-making [6], with $21.62 \%$ of clarified variance; $\alpha=0.93$ (M $=2.56, \mathrm{SD}=1.304)$.

- WE - work exploration [33] (comprising items focused to apply SNSs for networking with employers, recruiters and participating in discussions regarding jobs and presenting work experiences and employability competences) is consistent with active identity-making [6], with $15.63 \%$ of clarified variance; $\alpha=0.89(\mathrm{M}=2.15, \mathrm{SD}=$ 1.308).

- NL - networking for learning appeared as an independent dimension. In Kuijpers and Scheerens' [33] model the self-presentation portion is consistent with narrative and reflective identity-making [6]. NL as an independent dimension comprises items representing networking for the exploration of local and global career and professional events and seeking social support in career development. This independent dimension is consistent with active identity-making [6], with $11.42 \%$ of clarified variance; $\alpha$ $=0.89(\mathrm{M}=2.99, \mathrm{SD}=1.404)$.

- CR - career reflection [33] (comprising items regarding active engagement in discussions about one's own work and professional experiences, including about the transfer of competency from academic to work contexts) is consistent with reflective identity-making [6], with $8.90 \%$ of clarified variance; $\alpha=0.81(\mathrm{M}=2.56, \mathrm{SD}=$ 1.286). 
- SP - self-presentation [33] as a professional (comprising items regarding applying SNSs for professional presentation and agreeing that routines of publishing about one's career are important, that designing SNS profiles develops abilities for professional presentation and that such profiles build a narrative indicating main turning points in life) is consistent with narrative and reflective identity-making [6], with $6.60 \%$ of clarified variance; $\alpha=0.83(\mathrm{M}=2.64, \mathrm{SD}=1.307)$. The results of the Keiser-Meyer-Olkin measure support the application of the functions of factor analysis $(\mathrm{KMO} \geq 0.5)$ and the sampling strategies [37].

The findings support Hypothesis 1. The additional factor of networking for learning and the development of career competences was also identified, consistent with Orsatti and Riemer's [6] theory of active identity-making. All mean values are low: below 3 on the scale from 1 to 5 . However, the respondents held the most positive attitudes concerning NL, or networking for learning and the development of career competences $(\mathrm{M}=2.99$, $\mathrm{SD}=1.404)$. The lowest means indicates component of attitudes concerning WE, or work exploration $(\mathrm{M}=2.15, \mathrm{SD}=1.308)$. Other factors, including those concerning $\mathrm{CC}$ (career control; $\mathrm{M}=2.56, \mathrm{SD}=1.304$ ), $\mathrm{CR}$ (career reflection; $\mathrm{M}=2.56, \mathrm{SD}=1.286$ ), and $\mathrm{SP}$ (self-presentation; $\mathrm{M}=2.64, \mathrm{SD}=1.307$ ), indicate more neutral attitudes.

\subsection{Impact of attitudes on the actual use of SNSs for career management competences and for professional identity development}

To examine the significance of the impact of the students' attitudes, as reflected in the five factors, on their use of SNSs for career management competences and for professional identity development, a multiple regression analysis was conducted. The impacts of the individual factors are presented in Table 2 and Table 3. The results for the students' use of SNSs for career management competences yielded $\mathrm{M}=2.31$ ( $\mathrm{SD}=$ 1.183 ), and the results for the students' use of SNSs for professional identity development yielded $\mathrm{M}=3.21(\mathrm{SD}=1.230)$.

Table 2. The impact of factors on career management competences

\begin{tabular}{|c|l|c|c|c|c|c|c|}
\hline Model & Factors & $\mathbf{b}$ & $\mathbf{S E} \mathbf{B}$ & $\boldsymbol{\beta}$ & $\mathbf{p}$ & $\mathbf{R}^{\mathbf{2}}$ & $\mathbf{F}$ \\
\hline Model 1 & WE & $\mathbf{0 . 5 8 0}$ & $\mathbf{0 . 0 9 7}$ & $\mathbf{. 4 9 0}$ & $\mathbf{0 . 0 0 0 * *}$ & $\mathbf{2 4 . 0 \%}$ & $\mathbf{3 5 . 3 9 6}$ \\
\hline Model 2 & WE & 0.580 & 0.097 & .490 & 0.000 & & \\
\hline & SP & $\mathbf{0 . 4 2 6}$ & $\mathbf{0 . 0 8 9}$ & $\mathbf{. 3 6 0}$ & $\mathbf{0 . 0 0 0 * *}$ & $\mathbf{3 7 . 0 \%}$ & $\mathbf{2 2 . 7 8 9}$ \\
\hline Model 3 & WE & 0.580 & 0.097 & .490 & 0.000 & & \\
\hline & SP & 0.426 & 0.089 & .360 & 0.00 & & \\
\hline & CC & $\mathbf{0 . 4 1 7}$ & $\mathbf{0 . 0 8 0}$ & $\mathbf{. 3 5 3}$ & $\mathbf{0 . 0 0 0 * *}$ & $\mathbf{4 9 . 4 \%}$ & $\mathbf{2 7 . 0 4 4}$ \\
\hline Model 4 & WE & 0.580 & 0.097 & .490 & 0.000 & & \\
\hline & SP & 0.426 & 0.089 & .360 & 0.000 & & \\
\hline & CC & 0.417 & 0.080 & .353 & 0.000 & & \\
\hline & CR & $\mathbf{0 . 2 0 3}$ & $\mathbf{0 . 0 7 8}$ & $\mathbf{. 1 7 1}$ & $\mathbf{0 . 0 1 1 *}$ & $\mathbf{5 2 . 3 \%}$ & $\mathbf{6 . 7 2 4}$ \\
\hline
\end{tabular}

*Significance at $\mathrm{p}<0.05 ; * *$ Significance at $\mathrm{p}<0.01$; Durbin-Watson 1.946; 
The model that includes the predictor variable WE in the students' use of SNSs for career management competences explains $24.0 \%$ of the total variance $(\mathrm{R} 2=24.0 \%, \mathrm{~F}$ $=35,396, \mathrm{p}=0.000)$. The component NL was excluded from the Stepwise process as in the model as does not improve its explanation of variance. The model that also includes SP explains an additional $13 \%$ of variance $(\mathrm{R} 2=37 \%, \mathrm{~F}=22,789, \mathrm{p}=$ 0.000 ). The model that also includes $\mathrm{CC}$ explains an additional $12.4 \%$ of variance (R2 $=63.1 \%, \mathrm{~F}=27,044, \mathrm{p}=0.000)$. The model that also includes CR explains an additional $2,9 \%$ of variance $(\mathrm{R} 2=52,3 \%, \mathrm{~F}=6,724, \mathrm{p}=0.011)$. These findings partly support Hypothesis 2: Students' attitudes towards SNSs as support tools for work exploration, self-presentation, career control and career reflection, positively affect their actual SNS use for career management competences.

Table 3. The impact of factors on professional identity development

\begin{tabular}{|c|l|c|c|c|c|c|c|}
\hline Model & Factors & $\mathbf{b}$ & $\mathbf{S E}$ B & $\boldsymbol{\beta}$ & $\mathbf{p}$ & $\mathbf{R}^{\mathbf{2}}$ & $\mathbf{F}$ \\
\hline Model 1 & CC & $\mathbf{0 . 5 5 7}$ & $\mathbf{0 . 0 8 7}$ & $\mathbf{. 4 4 9}$ & $\mathbf{0 . 0 0 0 * *}$ & $\mathbf{2 0 . 2 \%}$ & $\mathbf{2 8 . 3 2 6}$ \\
\hline Model 2 & CC & 0.557 & 0.087 & .449 & 0.000 & & \\
\hline & NL & $\mathbf{0 . 4 4 5}$ & $\mathbf{0 . 0 9 6}$ & $\mathbf{. 3 5 9}$ & $\mathbf{0 . 0 6 5}$ & $\mathbf{3 3 . 1 \%}$ & $\mathbf{2 1 . 3 9 3}$ \\
\hline Model 3 & CC & 0.557 & 0.092 & .449 & 0.000 & & \\
\hline & NL & 0.445 & 0.093 & .359 & 0.065 & & \\
\hline & SP & $\mathbf{0 . 2 9 1}$ & $\mathbf{0 . 0 9 3}$ & $\mathbf{. 2 3 5}$ & $\mathbf{0 . 0 0 0 * *}$ & $\mathbf{3 8 . 6 \%}$ & $\mathbf{9 . 3 9 3}$ \\
\hline & CC & 0.557 & 0.092 & .449 & 0.000 & & \\
\hline & NL & 0.445 & 0.093 & .359 & 0.065 & & \\
\hline & SP & 0.291 & 0.093 & .235 & 0.000 & & $\mathbf{4 . 7 0 6}$ \\
\hline & CR & $\mathbf{0 . 1 9 8}$ & $\mathbf{0 . 0 9 1}$ & $\mathbf{. 1 5 9}$ & $\mathbf{0 . 0 0 2 *}$ & $\mathbf{4 1 . 1 \%}$ & \\
\hline & CC & 0.557 & 0.092 & .449 & 0.000 & & \\
\hline & NL & 0.445 & 0.093 & .359 & 0.065 & & \\
\hline & SP & 0.291 & 0.093 & .235 & 0.000 & & \\
\hline & CR & 0.198 & 0.091 & .159 & 0.002 & & $\mathbf{4 . 4 6 5}$ \\
\hline
\end{tabular}

*Significance at $\mathrm{p}<0.05 ; * *$ Significance at $\mathrm{p}<0.01$; Durbin-Watson 1.872;

In the students' use of SNSs for professional identity development, the predictor variable $\mathrm{CC}$ explains the highest amount of variance $(\mathrm{R} 2=20.2 \%, \mathrm{~F}=28,326, \mathrm{p}=$ $0.000)$. Adding the factor NL explains an additional $13.1 \%$ of variance $(\mathrm{R} 2=33.1 \%$, $\mathrm{F}=21,393, \mathrm{p}=0.000)$. However, the additional predictors do not add much to the variance explained. Adding the factor SP explains an additional 5.5\% of variance (R2 $=38.6 \%, \mathrm{~F}=9,860, \mathrm{p}=0.002), \mathrm{CR}$ explains additional $2.5 \%$ of variance $(\mathrm{R} 2=$ $20.2 \%, \mathrm{~F}=4,706, \mathrm{p}=0.032)$, and $\mathrm{WE}$ explains additional $2.5 \%(\mathrm{R} 2=20.2 \%, \mathrm{~F}=$ $4.650, \mathrm{p}=0.033)$. We can conclude that the predictor variables CR and WE explain little variance in the value of the outcome variable. These findings partly support Hypothesis 3: Students' attitudes about SNSs as support tools for career control, networking for learning and self-presentation positively affect their actual SNS use for students' professional identity development. 


\section{Discussion}

Our review of related work identified a lack of published research on the use of SNSs for the development of online career competences [13]. The related research emphasises the role of SNSs for networking and self-presentation [13]; however, our study showed that students tended not to perceive SNSs as very important and did not frequently utilize them for their career management competences or professional identity development, as illustrated by low average means across five dimensions.

The results show that, though students perceive SNSs as useful and utilise them for professional and career purposes; all our respondents had a Facebook account and only $24 \%$ of them (Table 1) had LinkedIn accounts. Similarly, low usages of LinkedIn among university students have been previously reported [10, 25]. These findings suggest that university students are not aware of the potential of SNSs for career management [9] or have unrealistic expectations or awareness of how to use them [10]. Prior studies have shown that companies are more focused on Facebook presences than on LinkedIn presences [27], though LinkedIn is increasingly used for e-recruitment purposes [26].

For students in this study, career control-related activities included items of attitudes towards SNSs for professional identity development, career decisions, attaining jobs during college and after graduation and belonging to a professional community. The results suggest that the students believed that SNSs could influence their professional identity development and that visibility on SNSs could influence future job prospects. The students felt that using SNSs for professional identity development and career management developed their competences in these areas more than other resources. All items represent, in a broader sense, what Kuijpers and Scheerens [33] identified as planning, work and control of learning.

Career reflection, according to Kuijpers and Scheerens [33], involves reflecting on capacities and motives. Items in this factor focused on active engagement in discussions about one's own professional experiences. SNSs offer students the opportunity to publicize and discuss their different work experiences within their networks and to involve themselves in discussions about professional events. Students can use SNSs to discuss their first experiences during practical placements, summer work and parttime jobs. In this way, students with work experiences can develop their competences to actively plan their next steps in their careers. SNSs, therefore, become places where students can present their experiences, connect with colleagues and get their first referrals.

Self-presentation, according to Kuijpers and Scheerens [33], comprises verbal career promotion, presentation and networking. It is consistent with Orsatti and Riemer's [6] narrative and reflective identity making. Personal branding in SNSs [5, 35] and SNS communication styles are characteristic in the professional field [8]. Items in this factor reflect attitudes and actual professional presentation. The students in this study believed that SNS activities related to careers and professions are important and that supports their skills in professional presentation. They used SNSs to develop professional presentations, to network with professional organizations and to build narratives indicating the main turning points in their lives. 
Networking for learning and the development of career competences, which were treated as part of self-presentation in the original model, emerged as an independent factor in our study. This factor is comparable to Orsati and Riemer's [6] active identity-making and comprises activities in which students search for professional events, career events and opportunities, seek social support in their career development and explore global potentials for their careers. Awareness of engineering studies as a global occupation is evolving via SNSs. Students use SNSs to seek social support, which has been found to be a result of networking about career aspirations [1]. Subrahmanyam and co-authors [38] report that young adults use SNSs to connect with people they know from their off-line lives to selectively strengthen different connections. These skills can be easily extended to the context of career and/or professional networking. Extensive networks allowing bridging and strong interpersonal ties that support bonding create valuable social capital, which can be important in one's professional career [10].

Work exploration comprises activities related to searching and networking with employers and the professional community [33]. Students are aware of the importance of work exploration, including contacting professional organizations, employers and recruiters; yet, the results show a low level of participation in these activities $(\mathrm{M}=$ $2.15, \mathrm{SD}=1.308)$. This could be due to the fact that students are not yet active job seekers and may still use traditional approaches to conduct their job searches during their study years. However, having an active LinkedIn account enables students to more easily transition from passive to active job seekers at the end of their studies [26].

The powerful impact of SNSs on the social construction of student professional identities should be more widely discussed, particularly in education institutions. Instructional implications indicate that actions need to be taken in order to support students' understandings of the impact SNSs have on shaping professional identities. Professional presentations and personal branding need to be addressed critically [5]. Furthermore, the use of SNSs for professional purposes should be introduced in educational settings to prepare students to more proactively shape their online academic and professional presentations.

Our study confirms that student attitudes are predictors of the use of SNSs for career management competences and professional identity development (Table 3). Influencing predictors in career management competences development include students' beliefs that SNSs support work exploration and processes of self-presentation and career control. Students are active in narrative identity-making (consistent with self-presentation) on Facebook and have reflective skills (consistent with career reflection). Students beliefs that SNSs support career reflection adds very little to explained variance. All these can be applied to foster career management competences.

In professional identity development, the strongest influencing predictors are students' beliefs that SNSs support career control and support their engagement in professional events, learning opportunities, networking for learning which they believe can support them in building their professional identities. Self-presentation, career reflection [3] and work exploration were all found as significant predictors for professional identity development but added very little to explained variance. According to 
Lave and Wenger [24], professional identity is developed primarily while students are situated in the core practices of their professional communities. SNSs are becoming increasingly used for building professional communities, and the findings of our study indicate that, within the dimension of career control, students believe that professional communities are accessible to them through SNSs (e.g. My activities in SNSs provide me with a sense of belonging to a professional community.).

\section{Conclusions}

This study highlights the ways in which students believe that SNSs influence their careers and shape their identities. SNSs have been shown to change employment practices [8] and shape professional identities [5], and studies have been conducted to identify competences needed with regard to managing careers via SNSs. The most important SNS-related career management competences are networking and selfpresentation [13], which build social capital [10]. However, career management competences integrate other important dimensions of career control, work reflection and work exploration. These dimensions of career management are manifested in SNSs as a career management tool. The findings of this study show that students' awareness of SNSs is not very strong (low average values); however, they also reveal the complexity of understanding career competences when engaging with SNSs.

These findings have informed the redesign of the course "Work-integrated Learning" for students in civil and geodetic engineering. Within the course, the objective of developing the students' SNS-related career management competences was integrated. In the short term, the students apply their competences in the process of initiating first contacts with employers when finding practical placement opportunities. The students explore potential employers, professional organizations and other professional profiles to become engaged in discussions, to reflect and plan their own future careers, to better understand the dynamics of current professionals' careers (domestic and international) in the fields in which they are trying to succeed and to plan their future studies (e.g. practical placement, elective courses, international exchange programs, etc.).

\section{Acknowledgment}

The authors acknowledge the financial support from the Slovenian Research Agency within a bilateral project BI-US/16-17-017 and research program ARRS P2-0210.

\section{References}

[1] J. Akkermans, W. B. Schaufeli,, V. Brenninkmeijer and R. W. B. Blonk, "The role of career competencies in the job demands-Resources model," Journal of Vocational Behavior, vol. 83, no. 3, pp. 356-366, 2013. https://doi.org/10.1016/j.jvb.2013.06.011 
Paper-Students' Attitudes on Social Network Sites and their Actual Use for Career Management Comp...

[2] D. Jackson and N. Wilton, "Developing career management competences among undergraduates and the role of work integrated learning," Teaching in Higher Education, vol. 21, no. 3, pp. 266-286, 2016. https://doi.org/10.1080/13562517.2015.1136281

[3] K. J. Stringer and J. L. Kerpelman, "Career identity development in college students: Decision making, parental support, and work experience," Identity, vol. 10, no. 3, pp. 181200, 2010. https://doi.org/10.1080/15283488.2010.496102

[4] C. Evans, "Developing career management skills within HE curriculum: A review and evaluation of different approaches," International Journal of Management Education, vol. 6, no. 3, pp. 45-55, 2008. https://doi.org/10.3794/ijme.63.152

[5] J. Novakovich, S. Miah and S. Shaw, "Designing curriculum to shape professional social media skills and identity in virtual communities of practice," Computers. \& Education, vol. 104, pp. 65-90, 2017. https://doi.org/10.1016/j.compedu.2016.11.002

[6] J. Orsatti and K. Riemer, "Identity-making: A multimodal approach for researching identity in social media," in Proc. European Conf. Information Systems (ECIS), Münster, Germany, 2015, pp. 1-18.

[7] N. B. Ellison and D. M. Boyd, "Sociality through social network sites," in The Oxford handbook of internet studies, W. H. Dutton, Ed. Oxford, UK: Oxford University Press, 2013, pp. 151-172.

[8] V. Smith, "Enhancing employability: Human, cultural, and social capital in an era of turbulent unpredictability," Human Relations, vol. 63, no. 2, pp. 279-303, 2010. https://doi.org/10.1177/0018726709353639

[9] V. Benson, S. Morgan and F. Fillippaios, "Online social networks: Changing the face of business education and career planning," International Journal of e-Business Management, vol. 4, no. 1, pp. 20-33, 2010. https://doi.org/10.3316/IJEBM0401020

[10] V. Benson, S. Morgan and F. Fillippaios, "Social career management: Social media and employability skills gap," Computers in Human Behavior, vol. 30, pp. 519-525, 2014 https://doi.org/10.1016/j.chb.2013.06.015

[11] V. Benson and S. Morgan, "Social university challenge: Constructing pragmatic graduate competencies for social networking," British Journal of Educational Technology, vol. 47, no. 3, pp. 465-473, 2016. https://doi.org/10.1111/bjet.12448

[12] A. Aluri and E. Tucker, "Social influence and technology acceptance: The use of personal social media as a career enhancement tool among college students," Journal of Hospitality \& Tourism Education, vol. 27, no. 2, pp. 48-59, 2015. https://doi.org/10.1080/10963758. 2015.1033103

[13] M. Rutten, A. Ros, M. Kuijpers and K. Kreijns, "Usefulness of social network sites for adolescents' development of online career skills," Educational Technology \& Society, vol. 19, no. 4, pp. 140-150, 2016.

[14] Y. Kim, D. Sohn and S. M. Choi, "Cultural difference in motivations for using social network sites: A comparative study of American and Korean college students," Computers in Human Behavior, vol. 27, no. 1, pp. 365-372, 2011. https://doi.org/10.1016/j.chb.20 $\underline{10.08 .015}$

[15] C. Madge, J. Meek, J. Wellens, and T. Hooley, "Facebook, social integration and informal learning at university: "It is more for socialising and talking to friends about work than for actually doing work," Learning, Media and Technology, vol. 34, no. 2, pp. 141-155, 2009. https://doi.org/10.1080/17439880902923606

[16] M. El Ouirdi, J. Segers, A. El Ouirdi and I. Pais, "Predictors of job seekers' self-disclosure on social media," Computers in Human Behavior, vol. 53, pp. 1-12, 2015. https://doi.org/10.1016/j.chb.2015.06.039 
[17] R. Miller, K. Parsons, and D. Lifer, "Students and social networking sites: The posting paradox," Behaviour \& Information Technology, vol. 29, no. 4, pp. 377-382, 2010. https://doi.org/10.1080/01449290903042491

[18] C. H. Christiansen, and G. T. Bryan, "Defining lives: Occupation as identity: An essay on competence, coherence, and the creation of meaning," American Journal of Occupational Therapy, vol. 53, no. 6, pp. 547-558, 1999. https://doi.org/10.5014/ajot.53.6.547

[19] S. Phelan and E. A. Kinsella, "Occupational identity: Engaging socio-cultural perspectives," Journal of Occupational Science, vol. 16, no. 2, pp. 85-91, 2009. https://doi.org/10.1080/14427591.2009.9686647

[20] A. Giddens, Modernity and self-identity: Self and society in the late modern age. Stanford, CA: Stanford University Press, 1991.

[21] E. Erikson, Identity: Youth and crisis. New York, NY: Norton, 1968.

[22] A. Giddens, The constitution of society. Outline of the theory of structuration. Berkeley and Los Angeles, CA: University of California Press, 1984.

[23] C. Lankshear and M. Knobel, New literacies: Everyday practices and social learning, 3rd ed. Buckingham, UK: Open University Press, 2011.

[24] J. Lave and E. Wenger, Situated learning: Legitimate peripheral participation. Cambridge, MA: Cambridge University Press, 1991. https://doi.org/10.1017/CBO9780511815355

[25] C. S. Ewing, "Perceptions of college students towards the use and usefulness of LinkedIn as a professional networking tool," Ph.D. dissertation (unpublished), Dept. Instructional Syst. and Workforce Develop., Mississippi State Univ., MS, 2016. [Online]. Available: http://search.proquest.com/docview/1783989512

[26] M. A. McKnight, M. S. Plouchard and M. N. Bizal, "Organizational hiring preferences: Comparison of traditional and non-traditional hiring and recruitment practices," International Journal of Human Resource Studies, vol. 5, no. 2, pp. 52-59, 2015. https://doi.org/10.5296/ijhrs.v5i2.7529

[27] Y. Melanthiou, F. Pavlou and E. Constantinou, "The use of social network sites as an erecruitment tool," Journal of Transnational Management, vol. 20, no. 1, pp. 31-49, 2015. https://doi.org/10.1080/15475778.2015.998141

[28] G. van Hoye, E. A. Hooft and F. Lievens, "Networking as a job search behaviour: A social network perspective," Journal of Occupational and Organizational Psychology, vol. 82, no. 3, pp. 661-682, 2009. https://doi.org/10.1348/096317908X360675

[29] R. Caers and V. Castelyns, "LinkedIn and Facebook in Belgium: The influences and biases of social network sites in recruitment and selection procedures," Social Science Computer Review, vol. 29, no. 4, pp. 437-448, 2010. https://doi.org/10.1177/0894439310386567

[30] M. Granovetter, Getting a job: A study of contacts and careers. Chicago, IL: University of Chicago Press, 1995.

[31] M. Klein and F. Weiss, "Is forcing them worth the effort? Benefits of mandatory internships for graduates from diverse family backgrounds at labour market entry," Studies in Higher Education, vol. 36, no. 8, pp. 269-987, 2011. https://doi.org/10.1080/03075079. 2010.487936

[32] R. Bridgstock, "The graduate tributes we've overlooked: Enhancing graduate employability through career management skills," Higher Education Research and development, vol. 28, no. 1, pp. 31-44, 2009. https://doi.org/10.1080/07294360802444347

[33] M. A. C. T. Kuijpers and J. Scheerens, "Career competencies for the modern career," Journal of Career Development, vol. 32, no. 4, pp. 303-319, 2006. https://doi.org/10.1177/0894845305283006 
[34] J. van Dijck, ““'You have one identity”: Performing the self on Facebook and LinkedIn,” Media, Culture \& Society, vol. 35, no. 2, pp. 199-215, 2013. https://doi.org/10.1177/ 0163443712468605

[35] S. Vallas and E. Cummins, "Personal branding and identity norms in the popular business press: Enterprise culture in an age of precarity," Organization Studies, vol. 36, no. 3, pp. 293-319, 2015. https://doi.org/10.1177/0170840614563741

[36] PewResearch Center (2015, October 8). Social media usage: 2005-2015. [Online]. Available: http://www.pewinternet.org/2015/10/08/social-networking-usage-2005-2015/.

[37] A. Field, Discovering statistics IBM SPSS statistics, 4th ed. Los Angeles, CA: SAGE, 2013.

[38] K. Subrahmanyam, S. M. Reich, N. Waechter and G. Espinoza, "Online and offline social networks: Use of social networking sites by emerging adults," Journal of Applied Developmental Psychology, vol. 29, pp. 420-433, 2008. https://doi.org/10.1016/j.appdev.2008. 07.003

[39] J. B. Walther, B. Van der Heide, S. Kim, D. Westerman and S. Tong, "The role of friends' appearance and behaviour on evaluation of individuals on Facebook: Are we known by the company we keep?," Human Communication Research, vol. 34, pp. 28-49, 2008. https://doi.org/10.1111/j.1468-2958.2007.00312.x

[40] Careerbuilder (2016, April 28). Annual CareerBuilder social media recruitment survey. [Online].Available: http://www.careerbuilder.com/share/aboutus/pressreleasesdetail.aspx? sd=4\%2F 28\%2F 2016\&id=pr945\&ed=12\%2F31\%2F 2016 .

[41] J. F. Hair, et al., Multivariate data analysis, 7th ed. Upper Saddle River, NJ: Prentice-Hall, 2010.

\section{Authors}

Andreja Istenic Starcic is with the Faculty of Civil and Geodetic Engineering, University of Ljubljana, Faculty of Education University of Primorska, Slovenia. She is a honorary fellow with Macquarie University Sydney, NSW, Australia and visiting professor with the Federal University of Kazan (Volga region), Kazan, Russia (email: andreja.starcic@gmail.com). Dr. Andreja Istenic Starcic is a Professor and a Vice dean at the Faculty of Education. Her teaching and research include Computers and Education, Educational technology, Social media and communication, User interface concepts supporting diverse user groups, Cognitive, social, affective aspects of human interactions with ICT, Professional identity, Professional learning, Work integrated learning, Teacher education. Andreja's website has details of her activities and publications: http://andreja-istenic-starcic.eu/.

Margaret Barrow is with the English department of Borough of Manhattan Community College/CUNY. Dr. Margaret Barrow is an Associate Professor and Deputy Chair in the English Department at BMCC/CUNY. Her research interest is focuses largely on pedagogy which include but is not limited to English Education, Discussion Practices, Ethics of care and teaching in higher education, and Digital Narratives. Dr. Barrow is organizer of the Transitions Transactions Conference.

Matej Zaje is with the Faculty of Electrical Engineering University of Ljubljana. Dr. Matej Zajc is an Associate professor. His research interests include Interactive multimedia systems and services, Human-computer interaction, Tangible interaction, 
Technology enhanced learning and Applications of ambient intelligence. He teaches undergraduate and graduate courses in the fields of ICT and multimedia. In Spring 2015 he was visiting professor at University of Washington, Human Centered Design and Engineering Department.

Maja Lebenicnik is with University of Primorska Faculty of Education. Maja Lebenicnik is a psychologist and a researcher. Her research interests include ICT in teaching and learning with a focus on Learning styles, Accessibility and Creative production of media contents. In her $\mathrm{PhD}$ she is focused on students with special needs and the use of ICT in higher education. She conducts a research of learning styles, in ICT supported learning environments with the Computer Department of University College Cork, Ireland.

Article submitted 15 February 2017. Published as resubmitted by the authors 23 April 2017. 